\title{
Pests, diseases and crop protection practices in the smallholder sweetpotato production system of the highlands of Papua New Guinea
}

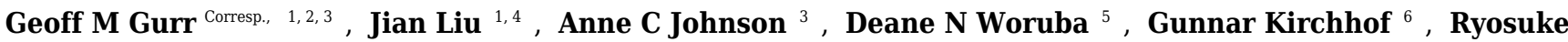 \\ Fujinuma $^{6}$, William Sirabis ${ }^{7}$, Yapo Jeffery ${ }^{7}$, Ramakrishna Akkinapally ${ }^{8}$ \\ ${ }^{1}$ State Key Laboratory of Ecological Pest Control for Fujian and Taiwan Crops, Fujian Agriculture \& Forestry University, Fuzhou, Fujian, China \\ 2 Institute of Applied Ecology, Fujian Agriculture \& Forestry University, Fuzhou, Fujian, China \\ 3 Graham Centre for Agricultural Innovation, Charles Sturt University, Orange, New South Wales, Australia \\ 4 Institute of Applied Ecology, Fujian Agriculture and Forestry University, Fuzhou, Fujian, China \\ 5 Elizabeth Macarthur Agricultural Institute, NSW Department of Primary Industries, Menangle, New South Wales, Australia \\ 6 School of Agriculture and Food Sciences, The University of Queensland, St Lucia, Queensland, Australia \\ 7 Highlands Regional Centre, National Agricultural Research Institute, Aiyura, Eastern Highlands Province, Papua New Guinea \\ 8 National Agricultural Research Institute, Lae, Morobe Province, Papua New Guinea \\ Corresponding Author: Geoff M Gurr \\ Email address: ggurr@csu.edu.au
}

Sweetpotato (Ipomea batatans) is a food crop of global significance. The storage roots and foliage of crop are attacked by a wide range of pests and diseases. Whilst these are generally well controlled in developed countries using approaches such as clean planting material and monitoring with pheromone traps to guide insecticide use, research into methods suitable for developing countries has lagged. In Papua New Guinea (PNG), sweetpotato is grown extensively as a subsistence crop and commercial production as a cash crop is developing. We report results from a survey of 33 smallholder producers located in the Highlands of PNG where the crop is of particular importance. Surveys of interviewees' crops showed high levels of pest and disease impact to foliage, stems and storage roots, especially in crops that were several years old. Weevils (Curculionidae) were reportedly the most damaging pests and scab (caused by the fungus Elisnoe batatus) the most damaging disease. Most producers reported root damage from the former and foliar damage from the latter but the general level of knowledge of pest and disease types was low. Despite the apparency of pest and disease signs and symptoms and recognition of their importance by farmers, a large majority of producers reported practiced no active pest or disease management. This was despite low numbers of farmers reporting use of traditional cultural practices including phytosanitary measures and insecticidal plants that had the scope for far wider use. Only one respondent reported use of insecticide though pesticides were available in nearby cities. This low level of pest and disease management in most cases, likely due to paucity in biological and technical knowledge among growers, 
hampers efforts to establish food security and constrains the development of sweetpotato as a cash crop. 
2 Pests, diseases and crop protection practices in the smallholder

3 sweetpotato production system of the highlands of Papua New

\section{Guinea}

7 Geoff M Gurr ${ }^{1,2,3 *}$, Jian Liu ${ }^{1,2}$, Anne C Johnson ${ }^{3}$, Deane N Woruba ${ }^{4}$, Gunnar Kirchhof ,

8 Ryosuke Fujinuma $^{5}$, William Sirabis ${ }^{6}$, Yapo Jeffery ${ }^{7}$, Ramakrishna Akkinapally ${ }^{7}$

${ }^{1}$ State Key Laboratory of Ecological Pest Control for Fujian and Taiwan Crops, Fujian Agriculture and Forestry University, Fuzhou 350002, China; email: ggurr@csu.edu.au

${ }^{2}$ Institute of Applied Ecology, Fujian Agriculture and Forestry University, Fuzhou 350002, China

${ }^{3}$ Graham Centre for Agricultural Innovation (Charles Sturt University \& NSW Department of Primary Industries), PO Box 883, Orange, NSW 2800. Australia.ggurr@csu.edu.au

${ }^{4}$ NSW Department of Primary Industries, Elizabeth Macarthur Agricultural Institute,

17 Woodbridge Road, Menangle, NSW 2568, Australia. nabre3@gmail.com

${ }^{5}$ School of Agriculture and Food Sciences, The University of Queensland, St Lucia Queensland 4072, Australia.g.kirchhof1@uq.edu.au; R.fujinuma@uq.edu.au

\footnotetext{
${ }^{6}$ National Agricultural Research Institute, Highlands Regional Centre, Aiyura, P.O. Box 210,
} 
21 Ukarumpa 444, Eastern Highlands Province, Papua New Guinea. william.sirabis@nari.org.pg;

22 yapo.jeffery@nari.org.pg.

$23{ }^{7}$ National Agricultural Research Institute, P O Box 4415, Lae 411, Morobe Province, Papua

24 New Guinea. a.ramakrishna@nari.org.pg

$25 *$ Corresponding author 
27 Abstract

28 Sweetpotato (Ipomea batatas) is a food crop of global significance. The storage roots and foliage

29 of the crop are attacked by a wide range of pests and diseases. Whilst these are generally well

30 controlled in developed countries using approaches such as clean planting material and

31 monitoring with pheromone traps to guide insecticide use, research into methods suitable for

32 developing countries has lagged. In Papua New Guinea (PNG), sweetpotato is grown extensively as a subsistence crop and commercial production as a cash crop is developing. We report results from a survey of 33 smallholder producers located in multiple sites in the Highlands of PNG where the crop is of particular importance. Surveys of interviewees' crops showed high levels of pest and disease impact to foliage, stems and storage roots, especially in areas where many successive crops had been grown. Weevils (Curculionidae) were reportedly the most damaging pests and were present in crops. Symptoms of scab (caused by the fungus Elisnoe batatus) were the most common foliar symptoms and this was the disease of most concern to farmers. Most producers reported root damage from the former and foliar damage from the latter but the general level of knowledge of pest and disease types was low. Despite the apparency of pest and disease signs and symptoms and recognition of their importance by farmers, a large majority of producers reported practicing no active pest or disease management. This was despite the practice among some farmers of traditional cultural methods including phytosanitary measures and insecticidal plants that had the scope for wider use. Only one respondent reported use of insecticide though pesticides were available in nearby towns. This low level of pest and disease management, likely due to paucity in biological and technical knowledge among growers, hampers efforts to establish food security and constrains the development of sweetpotato as a cash crop. 
Introduction

53

54

55

56

57

58

59

60

61

62

63

64

65

66

67

68

69

70

71

Among globally important food crops, sweetpotato (Ipomoea batatus) ranks number seven (Clark et al. 2013) but has been the subject of far less research than other staples such as potato (Solanum tuberosum) and wheat (Triticum aestivum) (Clark et al. 2013). This reflects the fact sweetpotato is a relatively minor crop in most developed countries in contrast to its widespread production in many tropical and sub-tropical, developing regions such as Africa, southern Asia and the Pacific where it is important for local consumption in subsistence communities (Woolfe 1992, Bourke 2009, Loebenstein and Thottapilly 2009, Zhang et al. 2009). In these areas, sweetpotato is critical for food security as it is often a major source of calories as well as vitamins such as carotenoids which are vital in preventing malnutrition in children (Lebot 2010, Woolfe 1992, Kismul, Van den Broeck, and Lunde 2014).

The storage roots of sweetpotato have high sugar and water content making them highly susceptible to biotic threats, especially during storage and if roots have been damaged by harvesting or pest attack (Woolfe 1992). In developed country production systems, losses are prevented by the availability of infrastructure such as cool storage facilities and rapid transportation systems. In subsistence production systems, however, post-harvest losses are avoided only by progressive harvest on-demand for immediate use (Okonya et al. 2014); with the general lack of infrastructure otherwise leading to high levels of damage (Johnson and Gurr 2016). This slows the development of commercial production and the livelihood benefits that value chains and processing potentially offer to impoverished rural communities. 
72 Sweetpotato is attacked by around 300 species of arthropods (Talekar 1991) that can cause severe 73 to complete crop loss, as well as at least 30 diseases (Clark et al. 2013). Johnson and Gurr (2016)

74 provide a recent, comprehensive review of those most common in smallholder production. The 75 fact that sweetpotato is vegetatively propagated, either by storage root fragments (slips) or by stem cuttings means that there is high scope for transfer of pest and pathogen inoculm from old to new

crops. For example, eggs and larvae of the sweetpotato weevil Cylas formicarius (Fabricius), an especially important pest, can be found in these propagules (Hartemink et al. 2000). Still more difficult for subsistence farmers to manage is the fact that plant pathogen inoculm, especially of viruses, is readily multiplied and distributed in slips and cuttings (Clark et al. 2012). Pests and diseases of sweetpotato are generally well controlled in developed countries by the use of pathogen-tested (clean) planting material, pheromone trapping and pesticides (Clark et al. 2013, Jansson and Raman 1991). In developing countries, however, these technologies are less available, particularly in outlying areas, and often unaffordable, making subsistence growers more reliant on traditional practices. These cultural practices include 'slash and burn' production in which crops are established on newly-cleared land. However, population growth and associated land shortage makes it increasingly difficult to continue these cultural practices resulting in more intense production with shorter fallow periods (Bourke 2001). A further factor that exacerbates the potential impact of pests and diseases in developing countries is that sweetpotato is often grown in a small production unit (garden) as a series of consecutive crops for multiple years rather than as an annual cop rotated among multiple fields as in developed countries. This increases the time period over which pest densities and pathogen inoculum and infection levels can reach damaging levels, potentially compounded by depletion of nutrients from the soil resulting from repeated 
94 harvest of storage roots (Bailey 2009, Hughes et al. 2009, Kirchhof, Taraken, Ramakrishna, et al. 95 2009).

96 Overall, sweetpotato production in developing countries is critical for food security but threatened

97 - in a general sense - by pests and diseases; and effective management is difficult because well98 studied technologies that are used in developed counties are not appropriate. Further, traditional 99 practices that have allowed production for many generations are becoming less viable because of 100 land shortages whilst research on management approaches that can be implemented has lagged 101 because these regions are often lack funding and capacity for agricultural research. To address this 102 situation, the aim of this study was to capture data that would identify the major biotic threats to 103 sweetpotato production as a guide to future investment of research funding. The geographical 104 focus of the study was the Highlands of PNG where this crop is the main food staple and where 105 there are currently efforts to establish sweetpotato as a commercial cash crop. Whilst agronomic 106 and soil management issues in this region have been the subject of some earlier research (Kirchhof, 107 Taraken, Ratsch, et al. 2009, Wegener, Kirchhof, and Wilson 2009), no information has been 108 available on pests, diseases and their management. A group of the authors visited 33 farmers 109 spanning the major sweetpotato growing areas of the Highlands, conducting an extended interview 110 with each and collecting data from their crops. Retail outlets in the two major towns of the region 111 were also visited to determine the availability of pesticides.

\section{Methods}

114 Sweetpotato farmer surveys were conducted in the Highlands region of PNG in 2014 covering 115 the same sites used in a 2005 survey of farming systems and soil management (Kirchhof, 
116 Taraken, Ratsch, et al. 2009, Wegener, Kirchhof, and Wilson 2009). The survey covered the five

117 population centres of Asaro and Lufa in the Eastern Highlands Province, Gumni and Sinasina in

118 the Simbu Province, and Mount Hagen in the Western Highlands Province. The Highlands

119 region experiences sporadic outbreaks of inter-tribal conflicts and armed violence is common.

120 Significant areas of potentially productive land sited between population centres is either

121 uncultivated or is being overgrown with revegetation because it is considered too dangerous for

122 people to regularly cultivate. Reflecting these hazards, local officials, village extension workers

123 and police were used to facilitate an initial visit to population centres for the purposes of this

124 study. Armed police accompanied the research team for one centre. At each centre, a preliminary

125 meeting was held with the community in which authors able to speak the local dialect explained

126 the nature of the survey and sought their participation. Thereafter, six to seven farmers from each

127 village were surveyed, a total of 33. Conditions did not permit detailed assessments and

128 replicated destructive sampling for each site so the survey consisted of a rapid rural appraisal

129 (RRA) (Kirchhof, Taraken, Ratsch, et al. 2009). Responses of interviewees were recorded on a

130 standardised form in English. Interviewees were then asked to take the research team (4-5

131 persons depending on date) to a representative 'new garden' in which few successive

132 sweetpotato crops had been grown and a representative 'old garden' in which many successive

133 sweetpotato crops had been grown and that was planned to be placed into fallow or planted to a

134 non-sweetpotato crop in the near future. Gardens of both categories were made available on most

135 sites. A total of 27 varieties were reported from these gardens with I Don't Care (7), Wagi Besta

136 (4), Susan's Black Eye (2) and Carrot Kaukau (2) being the only varieties present in more than

137 one garden. All gardens were well established and producing storage roots at the time of

138 inspection. Yield data for the sites and the region in general are not available because 
139 sweetpotato is grown as a subsistence crop that is harvested in a progressive manner. Gardens

140 varied in size from approximately $50 \mathrm{~m}^{2}$ to $200 \mathrm{~m}^{2}$. This small size allowed the whole garden to

141 be visually assessed for presence/absence of foliar symptoms. Permission was sought to harvest

142 two, randomly selected sweetpotato plants from each garden. This was granted in a majority of

143 cases (more readily for old than newly-planted gardens). The base of the stems was split to

144 assess incidence of weevil larvae and their feeding tunnels and all of the storage roots beneath

145 sampled plants were inspected for the presence of holes smaller than $3 \mathrm{~mm}$ in diameter and holes

146 with greater diameter. Chi square analyses using the Quantpsy tool (Preacher 2001) were used to

147 compare old and new gardens, and compare the distribution of farmer responses within garden

148 ages.

149 Concurrent with the farmer survey, the senior author visited all rural supply retailers in the major

150 townships in the region, Goroka and Mount Hagen, to determine the availability of insecticide

151 and fungicide products.

152 Results

153 The 33 farmers made available for inspection a total of 27 newly planted gardens and 28 old 154 gardens.

155 Crop Inspections

156 The incidence of crops that were free of foliar symptoms was significantly $(\mathrm{P}<0.05)$ lower for

157 old than new gardens (Figure 1). Deformities of the young leaves symptomatic of scab disease, 158 caused by the fungus Elisnoe batatus Viégas \& Jenkins, were the most common symptoms in old 159 and new gardens. This was distinct from more general stunting of leaf size and discolouration 160 (including mosaic) characteristic of viral diseases which was observed as frequently as scab 
161 symptoms in the old gardens. Viral symptoms were significantly $(\mathrm{P}<0.05)$ less frequently

162 observed among new than old gardens (Figure 1). Splitting stem bases of sweetpotato vines was

163 possible for only some gardens because growers tended to be concerned about destructive

164 inspection of even a single plant because of the small size of the gardens but growers more

165 inclined to approve this in old gardens (Figure 2). Weevil larvae were detected in six of the 14

166 old gardens but only one of the 10 new gardens, however the small sample size meant that this

167 difference was not significantly different $(\mathrm{P}>0.05)$ (Figure 2$)$. For gardens of both ages, crops in

168 which holes were consistently absent from all storage roots sampled from both randomly

169 selected plants were in the minority (Figure 3). The storage roots in most of the old gardens had

170 small ( $<3 \mathrm{~mm}$ diameter) holes typical of sweetpotato weevil C. formicarius. Larger ( $>3 \mathrm{~mm}$

171 diameter) holes that may have been caused by the gregariously-feeding West Indian sweetpotato

172 weevil Euscepes postfasciatus (Fairmaire) as well as other pests such as molluscs and rats was

173 less common than smaller holes for gardens of both ages. For neither category of hole did the

174 incidence differ significantly between old and new gardens.

\section{Farmer responses}

176 New gardens reportedly had an average of 2.9 successive plantings (including the current crop)

177 with an average fallow period between crops of 11.40 months compared with 25.8 successive

178 plantings for old gardens with just 2.45 months between crops. Prior to the establishment of

179 these gardens, the new ones had an average of 7.56 years of fallow with responses as high as

180 "more than 50 years", whilst the old gardens were in fallow for 7.39 years with responses

181 extending to "too long ago to remember". Farmers' expectation of storage root yield were most

182 commonly high for new gardens and low for old gardens with differences between garden ages

183 very highly significant $(\mathrm{P}<0.001)$ (Figure 4). 
184 Very low number of farmers reported that their crops tended not to be attacked by pests and

185 diseases (Figure 5). Damage from these biotic factors was very much the norm. Chi square

186 analysis comparing the null hypothesis of uniform pest attack across all plant parts with the

187 farmers' reports of which plant parts were attacked showed significant $(\mathrm{p}<0.05)$ differences for

188 new gardens such that storage roots (the harvestable portion) were most attacked and roots least

189 attacked (Figure 5 a). The same trend across plant parts was apparent among old gardens but the

190 distribution of pest attack did not differ significantly from the null hypothesis. For diseases,

191 stems and leaves were reportedly most commonly attacked and roots least attacked, a trend that

192 was consistent across both garden ages and significantly different from the null hypothesis

$193(\mathrm{p}<0.05)$ within each age (Figure $5 \mathrm{~b})$. Caterpillars were considered a particular problem at the 5-

1946 month stage and gall mites and scab at harvest time.

195 Sweetpotato weevil (species unspecified) was ranked by the farmers as the crop protection issue 196 of greatest concern and for which they most wanted a solution. Chi square analysis comparing

197 the null hypothesis of all pest types reported with equal frequency with the farmers' reports

198 showed very highly significant $(\mathrm{p}<0.001)$ differences within new and old gardens (Figure 6).

199 This applied to the extent that weevils ranked more highly than all other biotic threat responses

200 combined. Gall mite was the second highest ranked pest priority for gardens of both ages whilst

201 grasshoppers and crickets were also specific concerns. Scab was the highest-ranked sweetpotato

202 disease problem, again in gardens of both ages. 'Nematode', 'tuber rot', 'rust' and other,

203 unknown diseases were also mentioned as biotic issues of concern. When asked to specify the

204 times of year pest were most problematic the responses were varied. For sweetpotato weevil,

205 attack was reported by farmers at widely varying times of the year and plant growth period but 
206 was mostly associated with the dry season. For crickets, planting and wet seasons were periods

207 of reported risk. Gall mites and scab were of greatest concern at harvest time.

208 Despite all farmers noticing pests and diseases (Figure 5) and considering pest damage,

209 particularly by weevils, as a concern (Figure 6) very few reported taking action to prevent or

210 control pest attack. The great majority of farmers reported taking no action to manage pests

211 (Figure 7 a). Chi square analysis comparing the null hypothesis of all pest management

212 approaches (including no control) being reported with equal frequency with the farmers' reports

213 showed very highly significant $(\mathrm{p}<0.001)$ differences for new and old gardens (Figure 7a). No

214 more than four farmers each used the soil management approaches of mounding-up over storage

215 roots or breaking up mounds to expose roots to heat; biological control with ants or chickens,

216 mulching with plant materials such as 'fish-kill' (Tephrosia spp.) or other insecticidal plants.

217 One farmer mentioned use of insecticide, Karate ${ }^{\circledR}$ (lambda-cyhalothrin) in his new garden. Only

218 one grower reported the use of a combination of methods, soil management with rogueing

219 (removal of infested stems), for pest management.

220 An equivalent lack of intervention was evident for disease management (Figure 7 b). Chi square

221 analysis comparing the null hypothesis of all disease management approaches (including no

222 control) being reported with equal frequency with the farmers' reports showed very highly

223 significant $(\mathrm{p}<0.001)$ differences for new and old gardens (Figure $7 \mathrm{~b})$. One grower reported the

224 use of 'clean planting material' but this was sourced from their own gardens rather than from a

225 pathogen-tested planting material scheme. In a separate question specifically about use of

226 planting material that was 'certified or disease tested', all farmers reported no such use. One

227 grower each reported rogueing (removal of symptomatic stems), fallowing and use of an

228 unspecified resistant variety. 


\section{Survey of pesticide availability}

230 A survey of the seven rural supply shops in the two major townships of Mount Hagen and

231 Goroka found that a small range of pesticides was available (Table 1). Of the eight insecticides

232 available, only lambda-cyhalothrin was sold in most shops. Chlorothalonil was the only

233 fungicide available in the two cities but on sale in most of the shops. Retailers reported these

234 were usually purchased for use on cash crops such as Irish potato (Solanum tuberosum), allowing

235 the cost of the input to be recouped, and rarely for use in sweetpotato since this was principally

236 for consumption by the extended family. In some stores, the pesticides were repackaged into

237 smaller, unlabelled packs for sale at low prices. More generally, labelling practices were not

238 stringent, with packs of one chlorothalonil product carrying the contradictory wording

239 'protective fungicide' and 'group Y herbicide' (Figure 8).

\section{Discussion}

242 Developing country pest and disease issues tend to receive less attention than those in developed

243 countries and this is compounded in regions where studies are made more difficult because of

244 instability and violence. Thus, though agricultural research in PNG has been the subject of

245 significant effort in recent years, there is a relative dearth of information to inform priorities and

246 investment. The present study of smallholder sweetpotato growers in the region of PNG, where

247 this crop is the main staple, provides strong evidence that pests and diseases are having a large

248 impact on production and that current management efforts are inadequate.

249 Among the biotic threats that farmers reported to be of high concern, weevils were paramount.

250 This was evident also in the assessment of damage to storage roots and inspections of stems in 
251 which weevils were frequently present. Internationally, the sweetpotato weevil is consistently

252 ranked as the most problematic pest in sweetpotato production (Ebregt et al. 2004, Fielding and

253 van Crowder 1995, Nsibande and McGeoch 1999, Okonya et al. 2014, Parr, Ntonifor, and Jackai

254 2014, Placide et al. 2015) though the damage can be confused with that from other pests such as

255 millipedes (Diplopoda) (Ebregt et al. 2004). Euscepes postfasciatus is present in PNG (Hughes

$2562013)$ and this causes some forms of damage similar to that of the sweetpotato weevil ( $C$.

257 formicarius). Though the adults of these two weevils are dissimilar in appearance, the immatures

258 look very similar. No farmers mentioned either species specifically so the relative importance of

259 these two species as pests remains to be determined. Certainly, both are potentially serious pests.

260 Weevil attack was reported by farmers at widely varying times of the year but was mostly

261 associated with the dry season, reflecting the fact that storage roots are more exposed to attack if

262 soil cracks as a result of dry conditions (Lutulele, 2001; Parr et al., 2014a) and this suggests that

263 impact could be more severe under climate change conditions (Okonya and Kroschel, 2013).

264 Native to the Indian subcontinent and eastwards to Malaysia, C. formicarius is a serious pest in

265 the south west Pacific, the southern USA, Caribbean and South America (Chalfant et al. 1990,

266 Sherman and Tamashiro 1954, Waterhouse and Norris 1987). Austin, Jansson, and Wolfe (1991)

267 and Horton and Ewell (1991) considered this pest of great importance in causing pre-harvest

268 damage. Euscepes postfasciatus originated from the Caribbean and is now a pest in the Pacific

269 region and South America (Katsuki et al. 2012, Raman and Alleyne 1991, Sherman and

270 Tamashiro 1954). An important mode of dispersal for both species is as immatures within

271 storage roots or stem cuttings (Hartemink et al. 2000, Ray, Mishra, and Mishra 1983). Larvae of

272 both weevil species feed on the storage root or within stems causing tunnelling packed with

273 frass. Adult E. postfasciatus tend to feed on storage roots gregariously, causing relatively few 
274 large holes. In contrast $C$. formicarius adults tend to feed individually causing smaller wounds

275 (Sherman and Tamashiro 1954). Accordingly, our classification of observed holes on storage

276 roots into $<3 \mathrm{~mm}$ and $>3 \mathrm{~mm}$ diameter provides an approximate indication that $C$. formicarius

277 may be the dominant weevil species. Clearly storage root holes could also be caused by other

278 pests, such as molluscs and rats, especially in the case of larger holes, so these results are

279 tentative. Studies based on rearing-out adults from infested storage roots or identifying

280 immatures (potentially aided by the development of molecular diagnostic tools) are necessary in

281 order to discriminate the incidence and impact of these two weevil species and plan appropriate

282 research and management priorities and such studies are currently underway.

283 Gall mite, Eriophyes gastrotrichus Nalepa (Acari: Eriophyidae), causes erinose, a foliar disease

284 characterised by blister-like galls on the stems of sweetpotato plants in the Philippines, and PNG

285 where it is has previously been reported to be a problem of increasing concern in the Highlands

286 (Ames et al. 1996, Hughes et al. 2009). This pest was the second most highly-rated concern

287 among growers. Since it infests the foliage, it is readily spread by stem cuttings which are

288 commonly used in the region. The use of slips or, more especially, pathogen-tested planting

289 material would allow crops to be established in a 'clean' state and allow production for some

290 time before field infection occurs. The Australian Centre for International Agricultural Research

291 has invested in establishing a pathogen-tested planting material program in the region. Whilst the

292 principal focus of this is control of viruses (see below) it would also benefit crop protection more

293 widely including for gall mite. In the present study, however, none of the farmers reported prior

294 use of planting material that was pathogen tested, certified or disease tested. Some reported use

295 of 'clean planting material' but this was sourced from their own or nearby gardens and illustrates

296 that they were aware of this infection pathway and the need to manage carryover of inoculum. 
297 Symptoms of scab, caused by Elsinoe batatas Viégas \& Jenkins, was the most commonly

298 observed form of foliar symptoms in both old and new gardens and was also the disease

299 considered of highest priority by farmers. Though the symptoms of this disease are characteristic

300 and unlikely to be confused with those of other diseases, pathogen isolation in future studies is

301 required to confirm identity. Throughout tropical regions, scab is considered the most serious

302 fungal disease of sweetpotato (Clark et al. 2013, Coleman et al. 2009). Though the storage roots

303 can be infected this tends to cause little impact; though foliar damage can be so severe that

304 photosynthetic area is reduced leading to storage root yield reductions as high as 34\% (Coleman

305 et al. 2009). Pathogen inoculum survives on crop residues and can be transmitted readily by stem

306 cuttings so is chiefly a problem when sweetpotato is grown continuously (Clark et al. 2013,

307 Coleman et al. 2009). It is noteworthy, then, that its incidence was high even in the new crop

308 gardens and this reflects the fact that no farmers had accessed pathogen-tested clean planting

309 material.

310 Viruses are widely considered to be of great economic importance in sweetpotato production

311 (Clark et al. 2012, Gibson and Kreuze 2014). A survey of scientists from less developed

312 countries rated viruses as the top priority (Fuglie 2007). Notably, however, no farmers in the

313 present study mentioned viruses though a large proportion of old gardens showed foliar

314 symptoms consistent with viral infection. As noted above, pathogen identification is required in

315 future work to confirm the precise cause of these symptoms. The apparent lack of concern

316 amongst growers about viral diseases likely reflects the fact that symptoms of viral infection can

317 be subtle and develop over a prolonged period with little or no direct symptoms on the storage

318 roots other than yield decline which is likely to be attributed to pests because of their greater

319 apparency. Related to this, the concept of a plant pathogenic virus, that has no signs, is relatively 
320 unfamiliar to many farmers so it not being mentioned is likely to reflect this fact. The availability

321 of molecular detection methods has led to rapid advances in sweetpotato virus knowledge and at

322 least 30 viruses of sweetpotato are known (Clark et al. 2012), some with multiple strains

323 (Dolores, Yebron, and Laurena 2012). Yields of virus-infected sweetpotato plants are often

324 severely affected, reduced by as much as 80-90\% (Carey et al. 1999, Clark et al. 2012, Davis and

325 Ruabete 2010). Though insects such as aphids such as Aphis gossypii and whiteflies including

326 Bemisia tabaci can transmit viruses (Clark et al. 2012, Byamukama et al. 2004), propagation

327 material is the chief means of viral spread (Gibson et al. 1997, Moyer and Larsen 1991,

328 Mbanzibwa et al. 2014). Foliar symptoms of virus infection include leaf distortion, strapping and

329 crinkling, mosaics, vein clearing, brown blotches and general stunting and chlorosis (Mbanzibwa

330 et al. 2014). These symotoms were significantly more frequenlty seen in old rather than new

331 gardens reflecting the time available for plant-to-plant transmision and build up of infection

332 levels.

333 These differences in pest and disease apparency between old and new gardens underscore the

334 importance of political action to establish peaceful rural communities in order to allow

335 potentially productive farmlands to be used. Prior to the establishment of these gardens, the new

336 ones had 7.56 years of fallow whilst the old gardens were in fallow for 7.39 year, less than half

337 as long as the $16.8(\mathrm{SE}=2.4)$ year reported for a 2005 survey of the same sites (Kirchhof,

338 Taraken, Ramakrishna, et al. 2009). This shortening of fallows reflects land shortages resulting

339 from rapidly increasing human population densities (Bourke, 2001) and is likely to allow pest

340 and disease pressure to increase because fallowing has been demonstrated to increase yields via

341 benefits to crop nutrition (Hartemink 2003, Hartemink et al. 2000). Accordingly, if farming

342 communities in the Highlands of New Guinea felt sufficiently safe to extend their cropping 
343 activities back into areas that has fallen out of production because of fear of inter-tribal violence,

344 this would alleviate both biotic and abiotic (nutritional) stress on crops.

345 A striking finding about pest and disease management practices among the surveyed growers is

346 the very large majority who reported not practicing any active management. This is despite the

347 existence of a potentially large number of methods that could be employed in this setting. Small

348 numbers of farmers reported using insecticidal plants, basic phytosanitation methods and simple

349 forms of biological control using ants or livestock. The makum system is a traditional PNG

350 practice for production of taro on mounds in which the ant, Pheidole megacephala (Fabricius),

351 has nested, and has been adapted for use in sweetpotato production (Sar et al. 2009). Ants are

352 also employed in a system in Cuba involving green tree ants being transported into sweetpotato

353 fields from banana plantations within their rolled banana leaf nests (Lagnaoui et al. 2000). Ants

354 can provide sweetpotato weevil control in a more cost effective than insecticides (Chalfant et al.

355 1990), so merits more attention as a method that could be readily adopted in smallholder

356 systems. It is not possible to determine from the present study why such low rates of pest and

357 disease management were apparent in the present study but the most likely explanation - based

358 on general interactions with the farming communities - is lack of knowledge. In particular,

359 though farmers recognised a range of pest and disease types, their knowledge of lifecycles and

360 essential concepts such as microscopic disease causing agents was rudimentary. Further, though

361 expectations of storage tuber yield from old gardens was lower than from new gardens, there was

362 a tendency to associate this with nutrient depletion. Associated with this, the adoption of

363 strategies to manage nutrition, such as not burning crop residues (Bailey 2009), could exacerbate

364 carryover of pests and pathogen inocula. 
365 A survey of sweetpotato growers in Tanzania found that although farmers could identify

366 diseased plants they could not distinguish the different types of disease (Adam, Sindi, and

367 Badstue 2015). Though those African farmers had a very limited knowledge of pests and

368 pathogens, they took at active precautions to manage them (Adam, Sindi, and Badstue 2015,

369 Nsibande and McGeoch 1999). For example, they identified plants that looked healthy and free

370 of pests for use in planting material (Adam, Sindi, and Badstue 2015). This was not widely

371 reported as a pest or disease management practice in the present survey though farmers are likely

372 to select relatively healthy cuttings on the basis of these being likely to root readily and grow

373 vigorously. The closer a village was to a main town or main road with passing traffic the more

374 likely the farmers in the Tanzanian study were to be able to identify diseases that affect

375 sweetpotato (Adam, Sindi, and Badstue 2015). Sites with easier access also tended to facilitate

376 the use of higher quality planting material. In the present study, all sites were accessible by roads

377 (Kirchhof, Taraken, Ratsch, et al. 2009) is it is likely that levels of knowledge and active pest

378 and disease management are still lower in the more remote areas of the PNG Highlands. Farmer

379 to farmer interactions are an important source of information sharing on pest management

380 (Adam, Sindi, and Badstue 2015, Pouratashi and Iravani 2012) but this communication channel

381 is impeded in PNG by tribal conflict and this underscores the importance of extension efforts and

382 initiatives such as the development of a pathogen-tested planting material scheme. Among the

383 challenges for such a scheme is that many dozens of sweetpotato varieties are grown in the

384 Highlands of PNG so the scheme would need to 'clean-up' and make available a wide range of

385 cultivars to meet farmers' needs.

387 Conclusion 
388 Like many developing countries, PNG is experiencing rapid population growth and government

389 policies are seeking to establish greater food security and livelihood development, the latter by

390 developing cash crops and value adding to agricultural commodities by processing and

391 marketing. Sweetpotato potentially can contribute strongly to both these objectives because it is

392 widely grown and culturally integral to traditional diets, yet strongly impacted by pests and

393 diseases that are not well managed. The recent IPES-Food (2016) 'Uniformity to Diversity'

394 Report highlighted the multiple negative outcomes from intensive agriculture in developed

395 countries. These include loss of biodiversity and reliance on non-renewable and environmentally

396 hazardous inputs including pesticides. Accordingly, the development trajectory of countries such

397 as PNG need to be cognizant of the negative aspects of simply following practices already

398 established in developed nation agricultural systems. For example, making pesticides more

399 readily available and promoting their use are not logical from the sustainability perspective and

400 would also complicate the common practice of feeding sweetpotato foliage to pigs. Production

401 needs to be increased to meet human needs but achieving this by becoming reliant on non-

402 renewable inputs and eroding the natural resource base of agriculture will lead to unsustainability

403 (Godfray 2011). As an alternative, ecological intensification (in which ecosystem services such

404 as biological pest control and nutrient cycling are key) offers viable benefits (Bommarco, Kleijn,

405 and Potts 2013). If wider use of pesticides is to be avoided, the need for alternative approaches is

406 clear but traditional practices of ancient agricultural systems, such as ants and livestock for

407 biological control, and insecticidal plants, can underpin this if their efficacy and utility are better

408 understood and appropriate extension efforts are made. Parallel with such technological efforts,

409 however, advances are necessary in the political and policy arena to make rural communities

410 safer and more sustainable. Recent human population growth and inter-tribal conflict over ever- 
411 more-scarce land has resulted in more intensive cropping in areas close to villages exacerbating

412 pest and disease build-up.

413

414

415

\section{Acknowledgement}

416

417

418

419

420

421

422

423

424

425

426

427

428

429

430

431

432

433

434

435

436

437

Mr. Kai Lali (NARI) drove and provided field support. Sargent Simon Wakala (PNG Royal Constabulary) assisted with security.

\section{References}

Adam, Rahma Isaack, Kirimi Sindi, and Lone Badstue. 2015. "Farmers' knowledge, perceptions and management of diseases affecting sweet potatoes in the Lake Victoria Zone region, Tanzania." Crop Protection 72 (0):97-107. doi: 10.1016/j.cropro.2015.02.010.

Ames, T, NEJM Smit, Ann R. Braun, JN O Sullivan, and Skoglund L.G. 1996. Sweetpotato: Major pests, diseases, and nutritional disorders. Peru: International Potato Center.

Austin, DF, RK Jansson, and GW Wolfe. 1991. "Convolvulaceae and Cylas: a proposed hypothesis on the origins of this plant/insect relationship." Tropical Agriculture 68 (2):162-170.

Bailey, J. 2009. "An evaluation of nutritional constraints on sweetpotato production in Papua New Guinea highlands using the diagnosis and recommendation inegration System (DRIS)." In Soil fertility in sweetpotato based cropping systems in the highlands of Papua New Guinea, edited by G. Kirchhof, 7-11. Canberra, ACT: Australian Centre for International Agricultural Research.

Bommarco, Riccardo, David Kleijn, and Simon G Potts. 2013. "Ecological intensification: harnessing ecosystem services for food security." Trends in Ecology \& Evolution 28 (4):230-238. doi: 10.1016/j.tree.2012.10.012.

Bourke, R. M. 2009. "Sweetpotato in Oceania." In The Sweetpotato, edited by G. Loebenstein and G. Thottapilly, 498-502. The Netherlands: Springer.

Bourke, R. Michael. 2001. "Intensification of Agricultural Systems in Papua New Guinea." Asia Pacific Viewpoint 42 (2-3):219-235. doi: 10.1111/1467-8373.00146. 
438

439

440

441

442

443

444

445

446

447

448

449

450

451

452

453

454

455

456

457

458

459

460

461

462

463

464

465

466

467

468

469

470

471

472

473

Byamukama, E., R. W. Gibson, V. Aritua, and E. Adipala. 2004. "Within-crop spread of sweet potato virus disease and the population dynamics of its whitefly and aphid vectors." Crop Protection 23 (2):109-116. doi: 10.1016/j.cropro.2003.07.003.

Carey, EE, RW Gibson, S Fuentes, M Machmud, ROM Mwanga, G Turyamureeba, L Zhang, D Ma, F Abo El-Abbas, and R El-Bedewy. 1999. The causes and control of virus diseases of sweetpotato in developing countries: Is sweetpotato virus disease the main problem? In Impact on changing world. 1997-98 Program Report. Lima, Peru: International Potato Centre.

Chalfant, R B, R K Jansson, D R Seal, and J M Schalk. 1990. "Ecology and management of sweet potato insects." Annual Review of Entomology 35 (1):157-180. doi: doi:10.1146/annurev.en.35.010190.001105.

Clark, C. A., DM Ferrin, TP Smith, and GJ Holmes, eds. 2013. Compendium of sweetpotato diseases, pests and disorders. Second ed. Minnesota, USA: APS Press.

Clark, Christopher A., Jeffrey A. Davis, Jorge A. Abad, Wilmer J. Cuellar, Segundo Fuentes, Jan F. Kreuze, Richard William Gibson, Settumba B. Mukasa, Arthur K. Tugume, Fred Donati Tairo, and Jari P. T. Valkonen. 2012. "Sweetpotato Viruses: 15 Years of Progress on Understanding and Managing Complex Diseases." Plant Disease 96 (2):168-185. doi: 10.1094/pdis-07-11-0550.

Coleman, E., M. Hughes, G. Jackson, B. Komolong, and E. Guaf. 2009. "Genetics and disease as factors in the yield decline of sweetpotato in the Papua New Guinea highlands." In Soil fertility in sweetpotato based cropping systems in the highlands of Papua New Guinea, edited by G. Kirchhof, 33-42. Canberra, ACT: Australian Centre for International Agricultural Research.

Davis, R. I., and T. K. Ruabete. 2010. "Records of plant pathogenic viruses and virus-like agents from 22 Pacific island countries and territories: a review and an update." Australasian Plant Pathology 39 (3):265-291. doi: 10.1071/AP10047.

Dolores, L. M., M. G. N. Yebron, Jr., and A. C. Laurena. 2012. "Molecular and biological characterization of selected Sweet potato feathery mottle virus (SPFMV) strains in the Philippines." Philippine Journal of Crop Science 37 (2):29-37.

Ebregt, E., P. C. Struik, P. E. Abidin, and B. Odongo. 2004. "Farmers' information on sweet potato production and millipede infestation in north-eastern Uganda. I. Associations between spatial and temporal crop diversity and the level of pest infestation." NJAS - Wageningen Journal of Life Sciences 52 (1):47-68. doi: 10.1016/S1573-5214(04)80029-0.

Fielding, W., and L. van Crowder. 1995. "Sweet potato weevils in Jamaica: Acceptable pests?" Journal of Sustainable Agriculture 5 (4):105-117.

Fuglie, KO. 2007. "Priorities for sweetpotato in developing countries: results of a survey." HortScience $42(5): 1200-1206$.

Gibson, R. W., and J. F. Kreuze. 2014. "Degeneration in sweetpotato due to viruses, virus-cleaned planting material and reversion: a review." Plant Pathology 64 (1):1-15. doi: 10.1111/ppa.12273. 
474

475

476

477

478

479

480

481

482

483

484

485

486

487

488

489

490

491

492

493

494

495

496

497

498

499

500

501

502

503

504

505

506

507

508

509

Gibson, R. W., R. O. M. Mwanga, S. Kasule, I. Mpembe, and E. E. Carey. 1997. "Apparent absence of viruses in most symptomless field-grown sweet potato in Uganda." Annals of Applied Biology 130 (3):481-490. doi: 10.1111/j.1744-7348.1997.tb07676.x.

Godfray, H Charles J. 2011. "Ecology, food and biodiversity." Science 333 (6047):1231-1232. doi: 10.1126/science.1211815.

Hartemink, AE. 2003. "Sweet potato yields and nutrient dynamics after short term fallows in the humid lowlands of Papua New Guinea." NJAS - Wageningen Journal of Life Sciences 50:297-319.

Hartemink, Alfred E., S. Poloma, M. Maino, K. S. Powell, J. Egenae, and J. N. O'Sullivan. 2000. "Yield decline of sweet potato in the humid lowlands of Papua New Guinea." Agriculture, Ecosystems \& Environment 79 (2-3):259-269. doi: 10.1016/S0167-8809(00)00139-0.

Horton, D.E., and P.T Ewell. 1991. "Sweet potato pest management: A social science perspective." In Sweet potato pest management: A global perspective, edited by R K Jansson and Kandukuri V. Raman, 407-428. San Francisco: Westview Press.

Hughes, M. 2013. Identifying appropriate strategies for reducing virus and weevil losses in sweetpotato production systems in Papua New Guinea and Australia. In Final report HORT/2011/053. Canberra, ACT: Australian Centre of International Agricultural Research.

Hughes, M., E. Coleman, Issac T. Taraken, and P. Igua. 2009. "Sweet potato agronomy in Papua New Guinea." In Soil fertility in sweetpotato based cropping systems in the highlands of Papua New Guinea, edited by G. Kirchhof, 7-11. Canberra: Australian Centre for International Agricultural Research.

IPES-Food. 2016. From uniformity to diversity: a paradigm shift from industrial agriculture to diversified agroecological systems. International Panel of Experts on Sustainable Food systems. www.ipesfood.org.

Jansson, R K, and Kandukuri V. Raman, eds. 1991. Sweet potato pest management: A Global perspective. San Francisco: Westview Press

Johnson, A. C., and G. M. Gurr. 2016. "Invertebrate pests and diseases of sweetpotato (Ipomoea batatas): a review and identification of research priorities for smallholder production." Annals of Applied Biology 168 (3):291-320. doi: 10.1111/aab.12265.

Katsuki, Masako, Yusuke Omae, Kensuke Okada, Toru Kamura, Takashi Matsuyama, Dai Haraguchi, Tsuguo Kohama, and Takahisa Miyatake. 2012. "Ultraviolet light-emitting diode (UV LED) trap the West Indian sweet potato weevil, Euscepes postfasciatus (Coleoptera: Curculionidae)." Applied Entomology and Zoology 47 (3):285-290. doi: 10.1007/s13355-012-0113-y.

Kirchhof, G., Issac T. Taraken, A. Ramakrishna, Rainer Ratsch, and P. Igua. 2009. "Biophysical contraints of sweetpotato-based cropping systems in the Papua New Guinea highlands." In Soil fertility in sweetpotato based cropping systems in the highlands of Papua New Guinea, edited by G. Kirchhof, 95-109. Canberra, ACT: Australian Centre for International Agricultural Research. 
510

511

512

513

514

515

516

517

518

519

520

521

522

523

524

525

526

527

528

529

530

531

532

533

534

535

536

537

538

539

540

541

542

543

544

Kirchhof, G., Issac T. Taraken, Rainer Ratsch, D. Kapal, and P. Igua. 2009. "Survey methodology to assess socioeconomic and biophysical contraints - lessons learnt in the highlands of Papua New Guinea." In Soil fertility in sweetpotato based cropping systems in the highlands of Papua New Guinea, edited by G. Kirchhof, 70-78. Canberra, ACT: Australian Centre for International Agricultural Research.

Kismul, H., J. Van den Broeck, and T. M. Lunde. 2014. "Diet and kwashiorkor: a prospective study from rural DR Congo." PeerJ 2:e350. doi: 10.7717/peerj.350.

Lagnaoui, A, F Cisneros, J Alcazar, and F Morales. 2000. A sustainable pest management strategy for sweetpotato weevil in Cuba: A success story: Food Fertilizer Technology Center.

Lebot, V. . 2010. "Sweetpotato." In Root and tuber crops, edited by J. E. Bradshaw, 97-125. New York, USA: Springer Science \& Business Media.

Loebenstein, G., and G. Thottapilly, eds. 2009. The Sweetpotato. Netherlands: Springer.

Mbanzibwa, D. R., A. K. Tugume, E. Chiunga, D. Mark, and F. D. Tairo. 2014. "Small RNA deep sequencing-based detection and further evidence of DNA viruses infecting sweetpotato plants in Tanzania." Annals of Applied Biology 165 (3):329-339. doi: 10.1111/aab.12136.

Moyer, J.W., and R.C Larsen. 1991. "Management of insect vectors of viruses infecting sweet potato." In Sweet potato pest management: A Global perspective, edited by R K Jansson and Kandukuri V. Raman, 341-358. San Francisco: Westview Press

Nsibande, M. L., and M. A. McGeoch. 1999. "Sweet potato, Ipomoea batatas (L), cropping practices and perceived production constraints in Swaziland: implications for pest management." International Journal of Pest Management 45 (1):29-33. doi: 10.1080/096708799228012.

Okonya, JS, R. Mwanga, K Syndikus, and J Kroschel. 2014. "Insect pests of sweetpotato in Uganda: farmers' perceptions of their importance and control practices." SpringerPlus 3 (303):1-10. doi: 10.1186/2193-1801-3-303.

Parr, MC, NN Ntonifor, and LE Jackai. 2014. "Effect of planting dates on the population dynamics of Cylas puncticollis and sweet potato storage roots damage in South Western Cameroon." Journal of Biology, Agriculture and Healthcare 4 (18):41-48.

Placide, R, H. Shimelis, M Laing, and D Gahakwa. 2015. "Farmers' perceptions, production and productivity constraints, preferences and breeding priorities of sweetpotato in Rwanda." HortScience 50 (1):36-43.

Pouratashi, Mahtab, and Hooshang Iravani. 2012. "Farmers' knowledge of integrated pest management and learning style preferences: Implications for information delivery." International Journal of Pest Management 58 (4):347-353. doi: 10.1080/09670874.2012.724468.

Preacher, K. 2001. "Calculation for the chi-square test: An interactive calculation tool for chi-square tests of goodness of fit and independence. [Computer software]." http://quantpsy.org. 
545

546

547

548

549

550

551

552

553

554

555

556

557

558

559

560

561

562

563

564

565

566

567

568

569

570

571

572
Raman, Kandukuri V., and E. H. Alleyne. 1991. "Biology and management of the West Indian sweet potato weevil, Euscepes postfasciatus." In Sweet potato pest management: A Global perspective, edited by R K Jansson and Kandukuri V. Raman, 263-281. San Francisco: Westview Press.

Ray, P. K., S. Mishra, and S. S. Mishra. 1983. "Sweet-potato productivity as affected by recurrent use of vines as planting-material." Scientia Horticulturae 20 (4):319-322. doi: 10.1016/03044238(83)90145-0.

Sar, Sim A, Christine King, Elske van de Fliert, Redley Opasa, Michael Atoai, Ana Appa, and Triya Papaya. 2009. "Engaging stakeholders through participatory research: Farmer innovations in the use of predatory ants for pest management in Papua New Guinea." Innovation Asia Pacific Symposium, Nepal, 4-7 May.

Sherman, Martin, and Minoru Tamashiro. 1954. The sweetpotato weevils in Hawaii: Their biology and control. In Technical Bulletin No. 23, edited by University of Hawaii Hawaii Agricultural Experimental Station. Hawaii: University of Hawaii.

Talekar, N.S. 1991. "Integrated Control of Cylas formicarius." In Sweet potato pest management: A Global perspective, edited by R K Jansson and Kandukuri V. Raman, 139-156. San Francisco: Westview Press.

Waterhouse, D. F., and K. R. Norris. 1987. Biological control, Pacific prospects. Edited by Research Australian Centre for International Agricultural. Melbourne: Melbourne : Inkata Press.

Wegener, M., G. Kirchhof, and T. Wilson. 2009. "An analysis of village garden management in the Papua New Guinea highlands." In Soil fertility in sweetpotato based cropping systems in the highlands of Papua New Guinea, edited by G. Kirchhof, 79-87. Canberra, ACT: Australian Centre for International Agricultural Research.

Woolfe, Jennifer A. 1992. Sweet potato: An untapped food resource. New York: Cambridge University Press.

Zhang, L., Q. Wang, Q. Liu, and Q. Wang. 2009. "Sweetpotato in China." In The Sweetpotato, edited by Gad Loebenstein and George Thottappilly, 325-358. Netherlands: Springer 
573 Table 1: Insecticide and fungicide availability in retail outlets in the Papua New Guinea Highlands 574 region townships of Goroka and Mount Hagen. (The anonymity of the retail suppliers is protected 575 by de-identification and the use of lettering)

576

\begin{tabular}{|c|c|c|c|}
\hline City & Retail Supplier & Product name and active constituent & Type \\
\hline \multirow[t]{11}{*}{ Goroka } & \multirow[t]{3}{*}{ A } & Karate $^{\circledR} 25 \mathrm{~g} / \mathrm{L}$; lambda-cyhalothrin & Insecticide \\
\hline & & Eko $^{\circledast} 720 \mathrm{~g} / \mathrm{L} ;$ chlorothalonil & Fungicide \\
\hline & & Barrek $^{\circledR} 500 \mathrm{~g} / \mathrm{L} ;$ chlorothalonil & Fungicide \\
\hline & \multirow[t]{3}{*}{ B } & Lambda $^{\circledR}$ C2.5EC; lambda-cyhalothrin & Insecticide \\
\hline & & Malathion ${ }^{\circledR}$; malathion & Insecticide \\
\hline & & Eko $^{\circledast} 720 \mathrm{~g} / \mathrm{L} ;$ chlorothalonil & Fungicide \\
\hline & \multirow[t]{4}{*}{ C } & Permethrin ${ }^{\circledR} 250$ EC; permethrin & Insecticide \\
\hline & & Lambda $^{\circledR}$ C2.5EC; lambda-cyhalothrin & Insecticide \\
\hline & & Bifenthrin ${ }^{\circledR} 10 \%$; bifenthrin & Insecticide \\
\hline & & Eko $^{\circledast} 720 \mathrm{~g} / \mathrm{L} ;$ chlorothalonil & Fungicide \\
\hline & $\mathrm{D}$ & Confidor $^{\circledR}$; imidacloprid & Insecticide \\
\hline \multirow{7}{*}{$\begin{array}{l}\text { Mount } \\
\text { Hagen }\end{array}$} & \multirow[t]{6}{*}{$E$} & Permethrin $^{\circledR}$; permethrin & Insecticide \\
\hline & & Carbofuran $^{\circledR} ;$ carbofuran & Insecticide \\
\hline & & Acephate $^{\circledR} 75 \% \mathrm{wv}$; acephate & Insecticide \\
\hline & & Bifenthrin ${ }^{\circledast}$; bifenthrin & Insecticide \\
\hline & & Chlorpyrifos $^{\circledR} 480 \mathrm{EC}$; chlorpyrifos & Insecticide \\
\hline & & Barrek $^{\circledR} 500 \mathrm{~g} / \mathrm{L} ;$ chlorothalonil & Fungicide \\
\hline & $\mathrm{F}$ & Eko $^{\circledR} 720 \mathrm{~g} / \mathrm{L} ;$ chlorothalonil & Fungicide \\
\hline
\end{tabular}


579

580

581

582

583

584

585

586

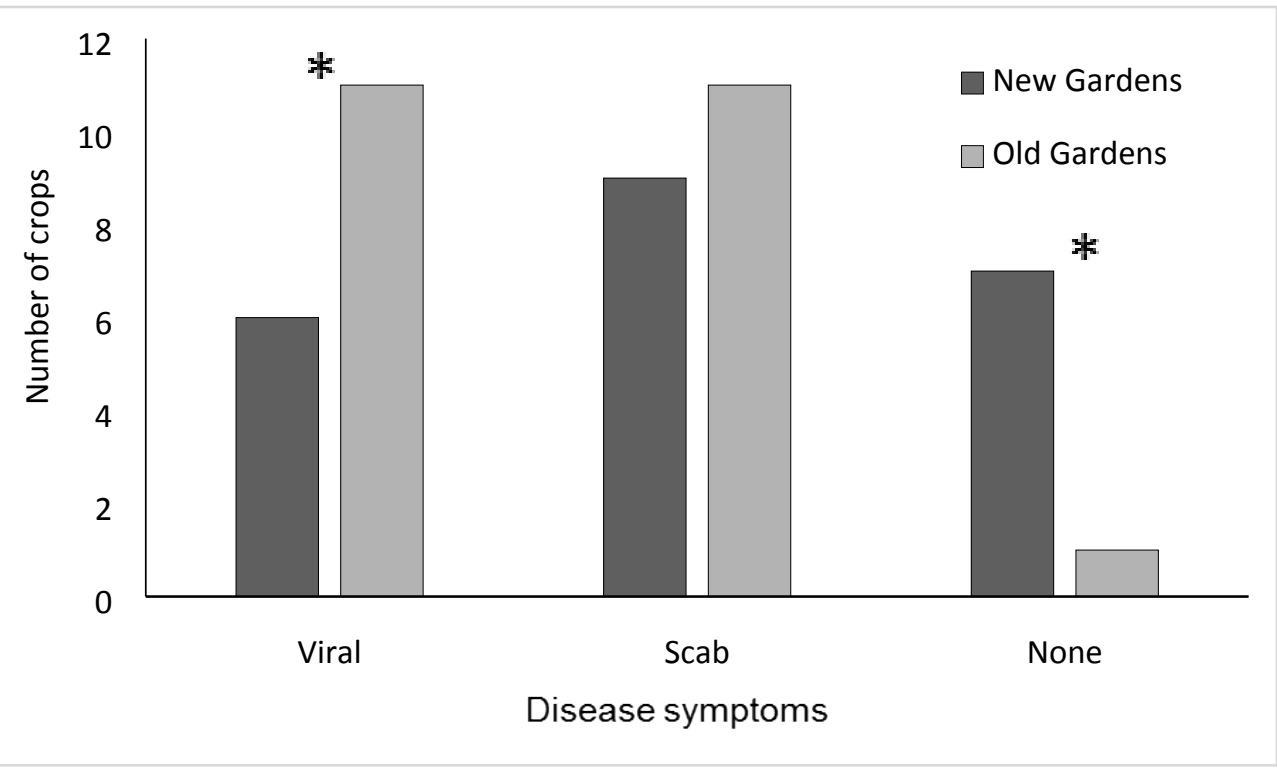

Figure 1. Incidence of foliar symptoms (viral infection and scab infection and symptom-free) among sweetpotato crops ( $\mathrm{n}=25$ new and 20 old). (Symptoms were non-mutually, exclusive; some crops had symptoms of more than one type. (Chi-square tests compared old and new gardens: viral, $X^{2}=4.543$, $\mathrm{df}=1, \mathrm{p}=0.033$; scab, $X^{2}=1.635$, $\mathrm{df}=1, \mathrm{p}=0.202$; no symptoms, $X^{2}=4.021, \mathrm{df}=1, \mathrm{p}=0.044$ ). 


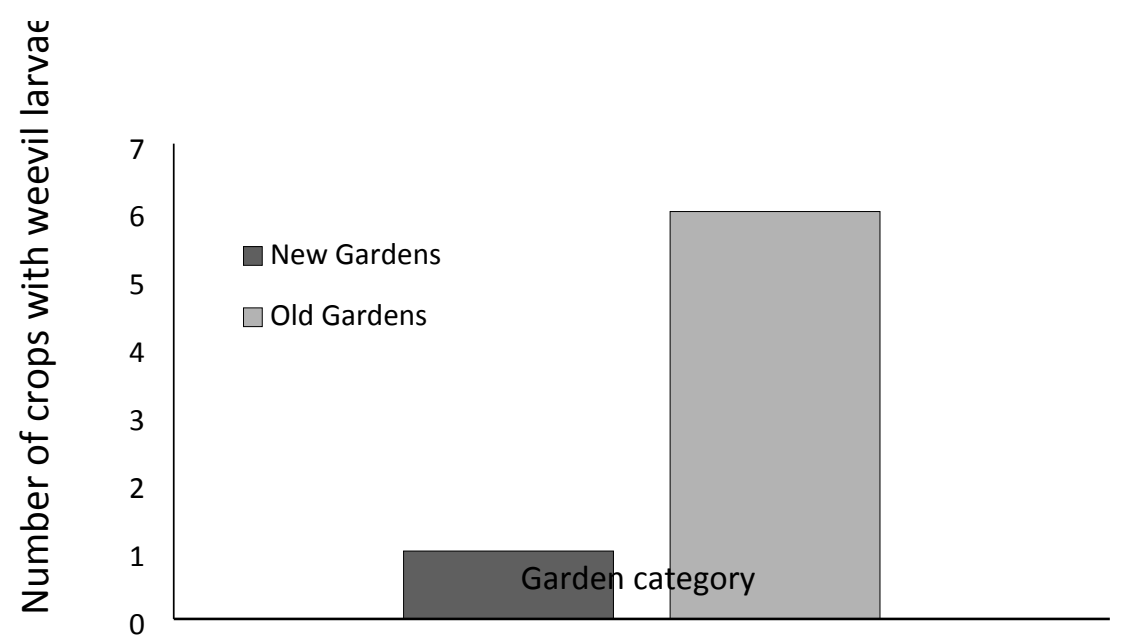

590

591 Figure 2. Incidence of weevils in the base of the stems among sweetpotato crops ( $n=10$ new and 14 old). 592 (Chi-square test compared old and new gardens $X^{2}=3.048, d f=1, p=0.081$ )

593

594

595 
Figure 3. Incidence of pest damage holes in sweetpotato storage roots ( $\mathrm{n}=10$ new and 14 old). (One crop

601

602

603

604 


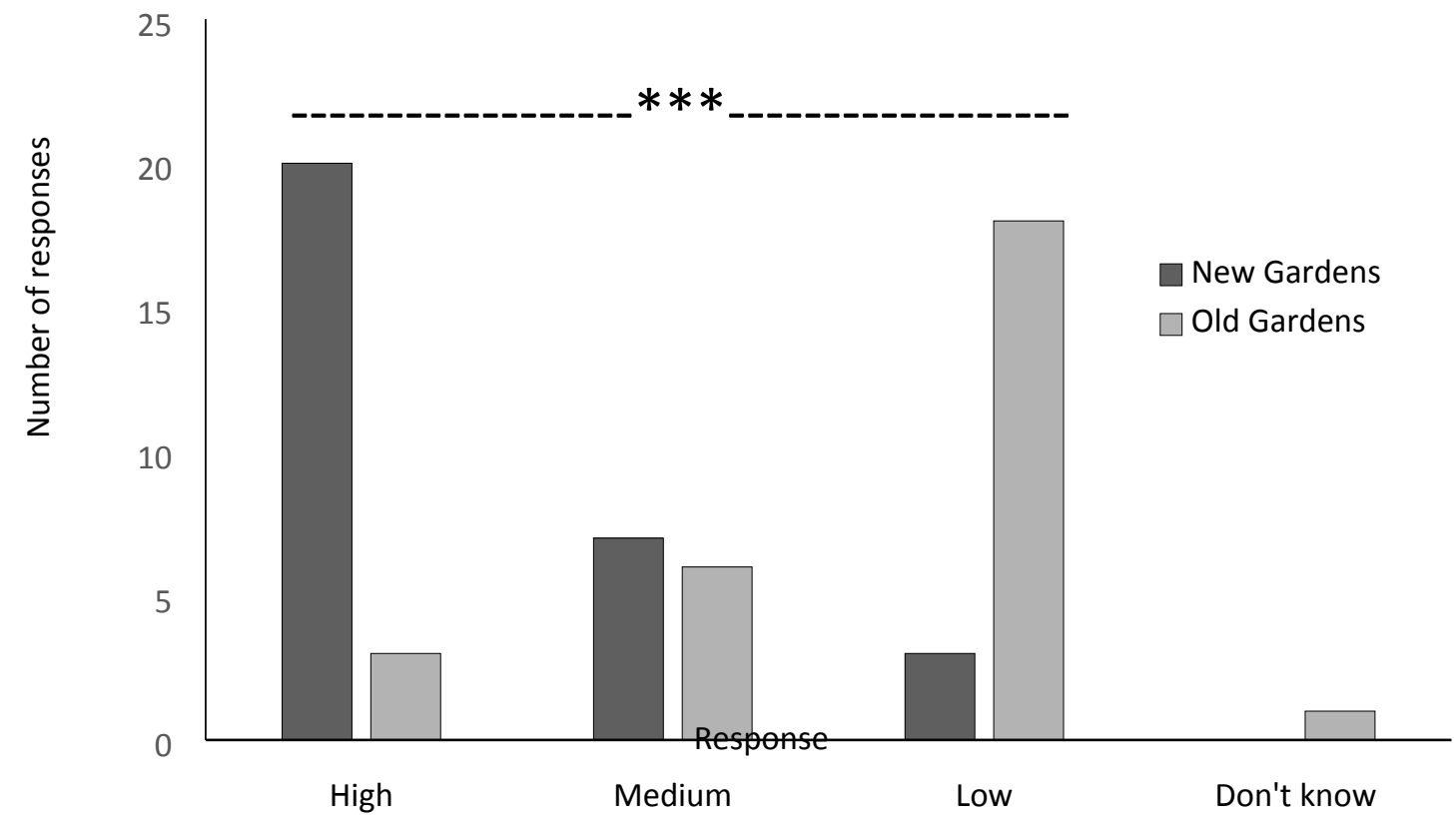

606

607 Figure 4. Yield expectation of farmers for new and old gardens. (Chi-square test compared 608 distribution of responses between garden ages: $X^{2}=24.316, d f=3, p<0.001$ )

609

610 
611

$612 a$

613

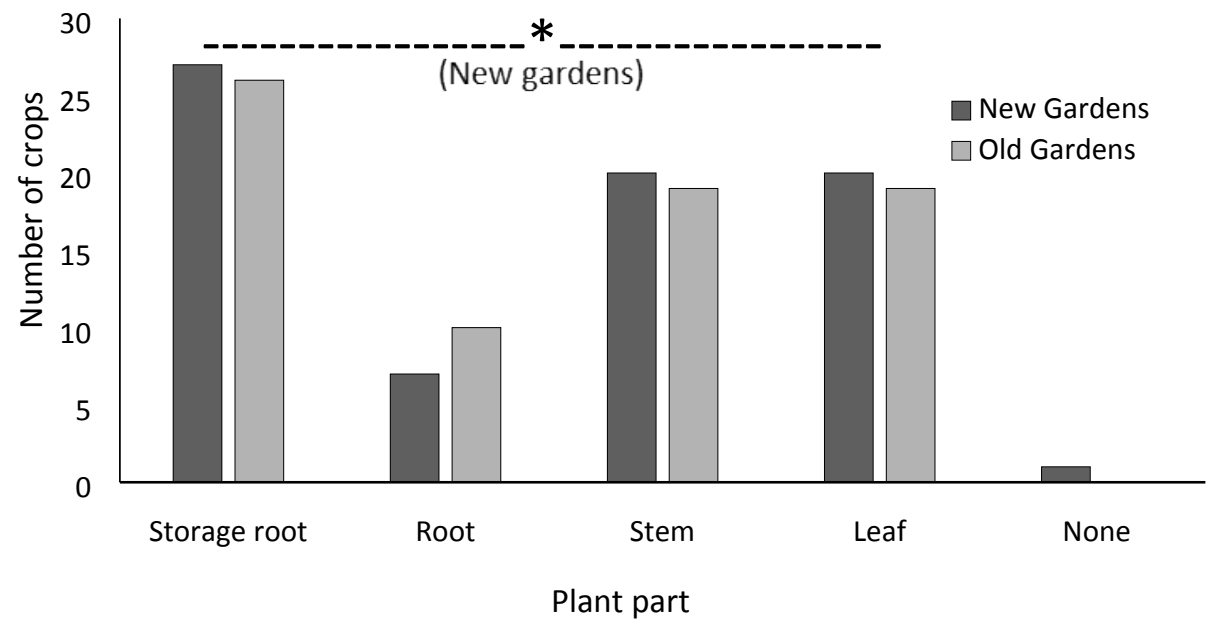

614

$615 \mathrm{~b}$

616

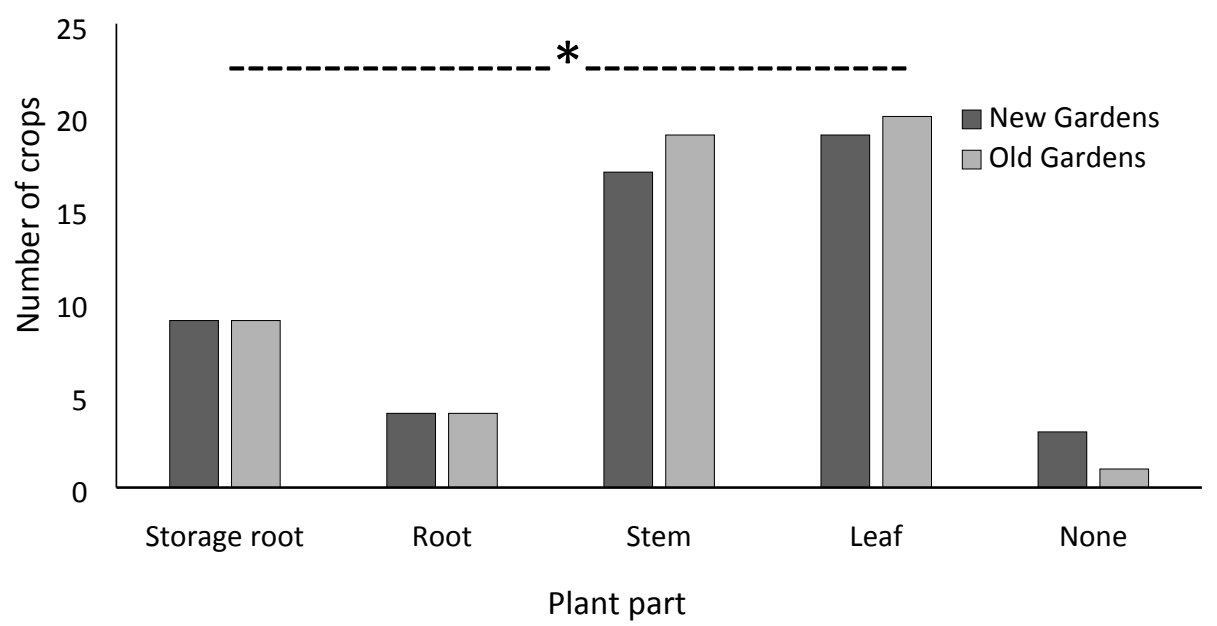

Figure 5. Farmers' responses on whether and where they observe damage by pests (a) and diseases (b). 621 (Means are the number of farmers mentioning a given concern and are non-mutually exclusive, some 
622

623

624

625

626

627

628

629

630

631

632

633

634

635

636 farmers mentioning one, and some multiple plant portions.) (Chi-square tests compared plant portions within each garden age: PESTS, new gardens, $X^{2}=7.849$, $d f=3, p=0.049$; old gardens, $X^{2}=4.524$, $d f=3$, $p=0.201$. DISEASES, old gardens: $X^{2}=8.544, d f=3, p=0.036$; old gardens, $X^{2}=9.9444, d f=3, p=0.0190$ )

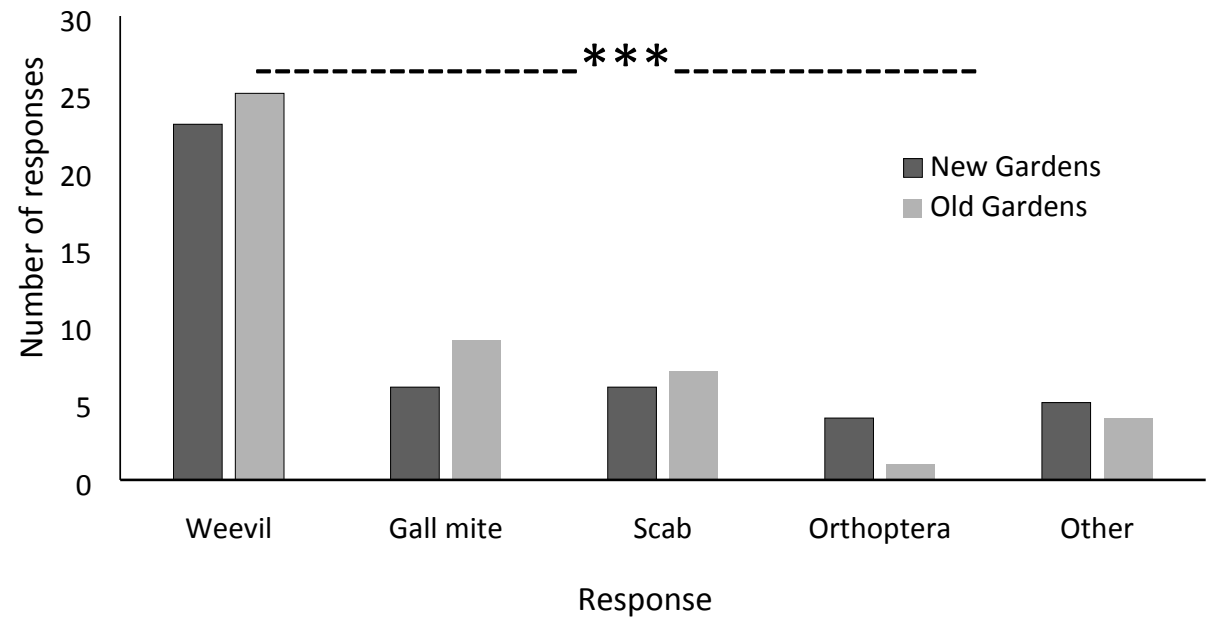

Figure 6. Plant protection issues cited in the top three concerns by farmers' for pest and disease problems. (Means are the number of farmers mentioning a given concern and are non-mutually exclusive, some farmers mentioning one, and some up to three issues. (Chi-square test compared pest types within each garden age: new gardens, priority is used by times been listed without giving any points. Weevil: $X^{2}=16.448, \mathrm{df}=4, \mathrm{p}=0.002$; old gardens, $X^{2}=23.836, \mathrm{df}=4, \mathrm{p}<0.001$ ) 


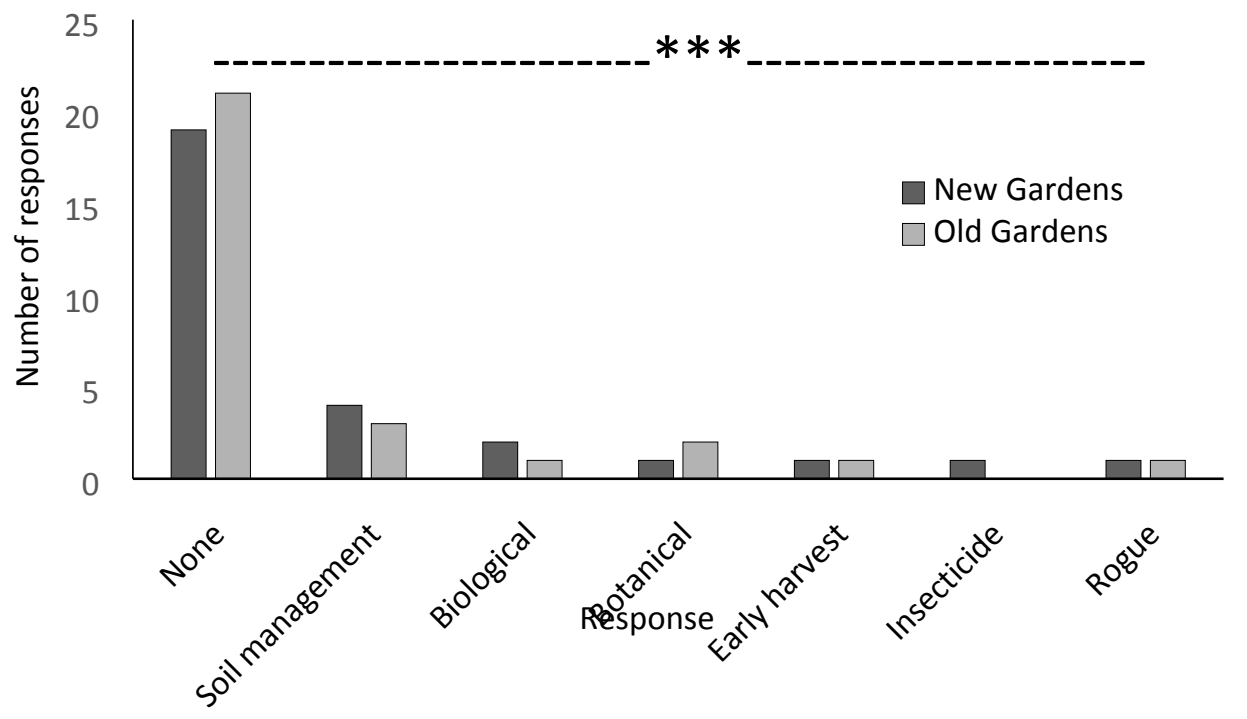

638

639 B

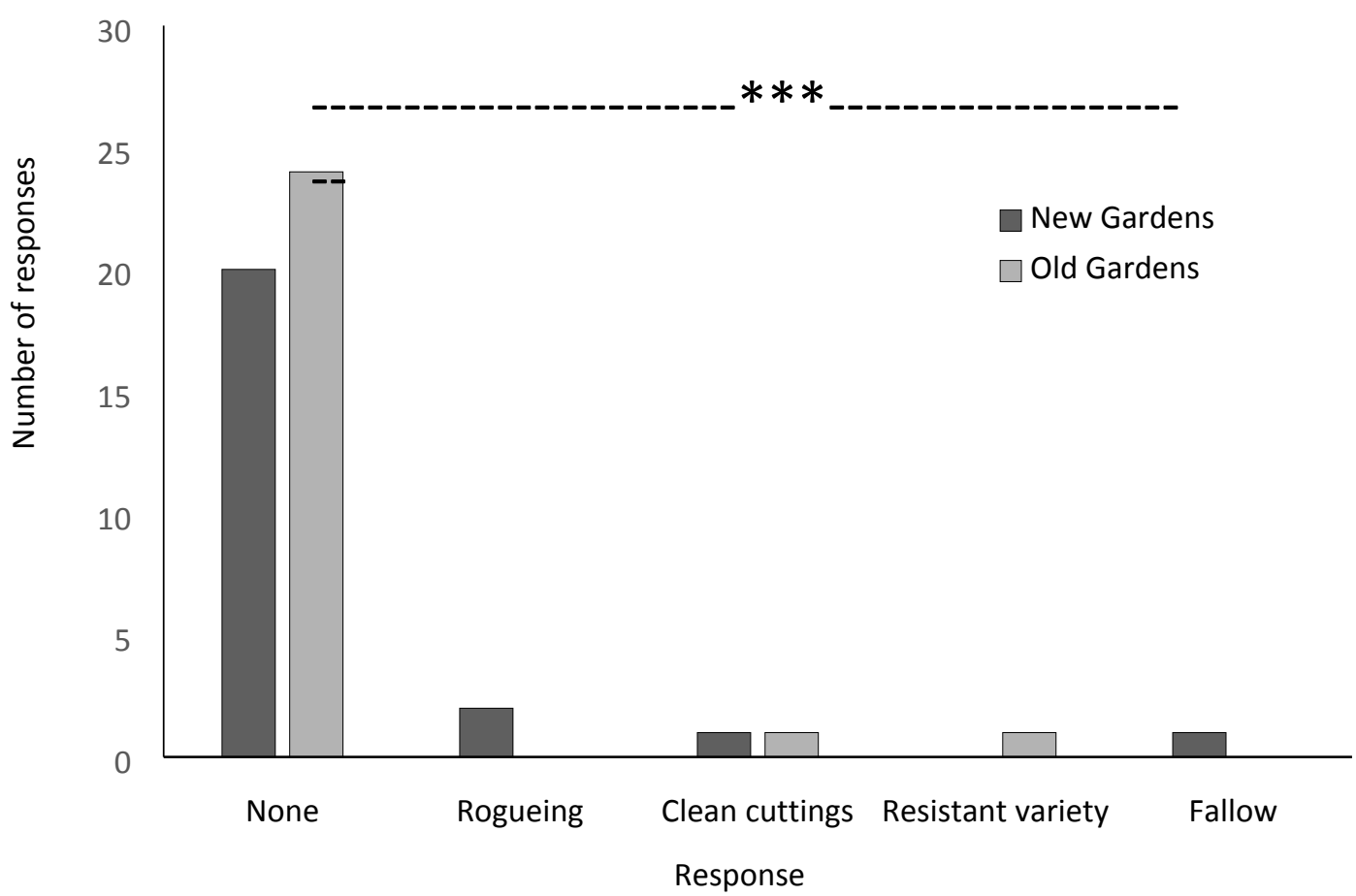

642 Figure 7. Reported actions taken to control pests (a) and diseases (b) on sweetpotato crops. (Chi-square 643 test compared management approaches within each garden age: PESTS, new gardens, $X^{2}=41.989$, df=6, 
$644 p<0.001$; old gardens, $X^{2}=52.738, d f=6, p<0.001$. DISEASES, new gardens, $X^{2}=38.338, d f=4, p<0.001$; 645 old gardens, $X^{2}=52.277, \mathrm{df}=4, \mathrm{p}<0.001$ )

646 
647

648

649

650

651

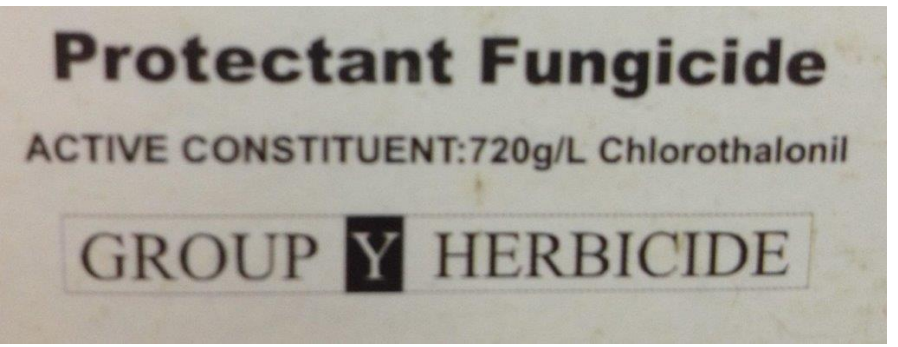

652

653

654 Figure 8: Example of pesticide labelling anomaly. Photograph from pesticide label on product for sale in 655 Goroka.

656 